\title{
Menyingkap Keagungan Karakter Rut dari dalam Bayang-Bayang: Penerapan Analisis Tokoh dalam Narasi Kitab Rut
}

\section{Uncovering the Noble Character of Ruth out of Shadows: Applying Character Analysis in the Book of Ruth}

\author{
Sia Kok Sin \\ Sekolah Tinggi Teologi Aletheia, Indonesia \\ Korespondensi: koksinsia@sttaletheia.ac.id
}

\begin{abstract}
Abstrak: Artikel ini berupaya untuk menerapkan analisis tokoh utama dalam kitab Rut untuk mengungkapkan keagungan dari karakter Rut dan mengidentifikasi respons pembaca mula-mula. Analisis tokoh dilakukan dengan menggunakan metode dari Richard L. Pratt Jr. yang meliputi pemaparan penokohan, teknik penokohan dan tujuan penokohan, untuk menyelidiki karakter Naomi, Rut dan Boas sebagai tiga tokoh utama dalam kitab ini. Ketiga tokoh utama ini dianalisis dan dibandingkan untuk menemukan tujuan penokohan dalam kitab ini dan berusaha untuk mengidentifikasi respons pembaca mula-mula. Penulis kitab Rut menghadirkan keagungan Rut itu dalam bayang-bayang keasingannya (sebagai perempuan Moab) dan tokoh utama lainnya, seperti Naomi dan Boas. Pembaca kitab Rut diharapkan dapat mengevaluasi kerohanian mereka sebagai umat Allah, oleh karena menemukan adanya perempuan Moab yang justru mempunyai kehidupan yang lebih saleh daripada mereka. Dari pembaca juga diharapkan bangkit kesadaran tentang Allah Israel yang terbuka untuk semua bangsa dan bahwa bangsa-bangsa lain tidak selalu membawa keburukan bagi kehidupan umat Allah.
\end{abstract}

Kata-kata kunci: Analisis Tokoh, Tujuan Penokohan, Respons Pembaca Mula-Mula, Keagungan Karakter Rut, Kitab Rut.

\begin{abstract}
This article is an effort to apply the character analysis in the book of Ruth that shows the excellence of Ruth and the response of the original readers. Character analysis was carried out using the method of Richard L. Pratt Jr., which includes the description of characterizations, characterization techniques, and characterization purposes, to investigate the characters of Naomi, Ruth, and Boaz as the three main characters in this book. These three characters are analyzed and compared to find the purpose of characterization and the reader's response. Through this analysis, we can find that the author of the book of Ruth has a purpose to describe indirectly or subtly the noble character of Ruth in the shadows of her background as a Moabites and the other main characters, Naomi and Boaz. Through the reading of the book of Ruth, the first readers can evaluate their spirituality as God's people because they find that there is a Moabite woman whose life is godlier than them. It also raises awareness that Israel's God embraces all nations and that non-Israelites do not always negatively influence God's people.
\end{abstract}

Keywords: Character Analysis, The Purpose of Characterization, The Response of Original Readers, The Noble Character of Ruth, The Book of Ruth 


\section{PENDAHULUAN}

Kitab Rut merupakan narasi yang menarik untuk dipelajari. Kitab ini merupakan contoh yang sangat baik untuk menafsirkan suatu narasi, karena merupakan kisah pendek yang lengkap dengan penanda narasi yang baik, seperti alur cerita yang menarik, pemaparan karakter yang berkembang dan makna yang dalam. ${ }^{1}$ Walaupun pembaca dapat mengikuti alur ceritanya dan mengidentifikasi para tokoh utamanya kitab ini dengan mudah, namun tetap dibutuhkan suatu penelitian untuk dapat menemukan makna dan nilai narasi ini. Analisis tokoh merupakan suatu hal yang penting dalam penelitian suatu narasi, karena makna dan nilai suatu narasi tersampaikan kepada pembaca melalui perkataan dan tindakan para tokoh. ${ }^{2}$

Analisis tokoh merupakan salah satu pendekatan sastra yang digunakan dalam studi kitab Rut $^{3}$ dan telah menghasilkan pelbagai penelitian yang penting. Analisis tokoh yang dilakukan oleh para peneliti umumnya tidak hanya berkaitan dengan satu tokoh utama dalam kitab Rut, tetapi berkaitan dua atau lebih tokoh utamanya. Upaya perbandingan di antara para tokoh utama ini penting untuk mempertajam hasil analisis tokoh ini. Beberapa penelitian analisis tokoh yang pernah dilakukan adalah sebagai berikut.

Fewell dan Gunn menganalisis karakter Naomi melalui perbandingannya dengan Rut

\footnotetext{
${ }^{1}$ Konstantin Nazarov, "Focalization in The Old Testament Narratives with Specific Examples from the Book of Ruth" (tesis, University of Chester, 2018), 15-16.

${ }^{2}$ Shimon Bar-Efart, Narrative Art in the Bible (Decatur: Almond, 1989), 47.

${ }^{3}$ Pendekatan studi kitab Rut dapat dikategorikan dalam beberapa jenis, yaitu pendekatan sejarah, sastra dan ilmu sosial. Peter H.W. Lau, Identity and Ethics in the Book of Ruth. A Social Identity Approach. (Berlin: Walter de Gruyter, 2010), 12-18.

${ }^{4}$ Danna Nolan Fewell dan David M. Gunn, “'A Son Is Born to Naomi!': Literary Allusions and Interpretation in the Book of Ruth," Journal for the Study of the Old Testament 40 (1988): 99-108.

${ }^{5}$ Ibid. Empat sikap diam ini akan penulis bahas dalam bagian penyelidikan tentang karakter Naomi.
}

untuk menolak pandangan bahwa Naomi merupakan seorang yang tidak mementingkan diri sendiri dan perhatian utamanya hanya kepada kesejahteraan menantunya. ${ }^{4}$ Mereka mengungkapkan adanya empat sikap diam Naomi dalam kaitannya dengan Rut yang dapat menjadi petunjuk bahwa Naomi adalah seorang yang tidak peduli, penuh kepahitan dan bahkan tidak segan membahayakan menantunya. ${ }^{5}$ Dalam artikel lainnya mereka juga menganalisis karakter Boas melalui perbandingan dengan Rut, khususnya dengan tiga pertanyaan utama tentang pernikahan Boas dengan Rut. Mereka berpendapat bahwa Boas adalah seorang yang pandai dalam hubungan publik, sehingga ia dapat menyelesaikan pernikahan dengan Rut, perempuan Moab itu tanpa kehilangan reputasinya sebagai seorang tokoh masyarakat. ${ }^{6}$

Saxegaard memaparkan kompleksitas karakter setiap tokoh. ${ }^{7}$ Ia mengungkapkan karakter Naomi yang kompleks. Ia adalah seorang yang disebut Naomi (menyenangkan), tetapi ia juga menyebut dirinya Mara (pahit). Ia nampaknya seperti seorang yang peduli terhadap kesejahteraan menantunya, tetapi ia menunjukkan sikap diam yang tidak pada tempatnya. Ia diam terhadap tekad Rut untuk ikut dengannya. Ia juga mendiamkan Allah. ${ }^{8}$ Ia juga berpendapat bahwa karakter Rut itu sebenarnya kompleks dan misterius, karena penyelidikan tokoh ini akan menghasilkan gambaran lain yang tidak selalu indah. ${ }^{9}$ Rut digambarkan tidak hanya sebagai menantu yang setia dan bijak, tetapi ia

\footnotetext{
${ }^{6}$ Tiga pertanyaan itu adalah mengapa Boas menikahi Rut, mengapa Boas enggan menikahi Rut, sehingga harus didesak, dan mengapa rencana pernikahannya dengan Rut harus dilakukan melalui konfrontasi dengan kerabat yang lebih dekat di depan umum. Fewell dan Gunn berpendapat jawaban ketiga pertanyaan itu terkait dengan upaya Boas mempertahankan status sebagai seorang tokoh masyarakat. Danna Nolan Fewell dan David M. Gunn, "Boaz, Pillar of Society: Measures of Worth in The Book of Ruth," Journal for the Study of the Old Testament 45 (1989): 45-59.

${ }^{7}$ Kristin Moen Saxegaard, Character Complexity in the Book of Ruth (Tübingen: Mohr Siebeck, 2010).

${ }^{8}$ Ibid., 103-104.

${ }^{9}$ Ibid., 105.
} 
juga seorang perempuan Moab dan pelayan yang menggoda. ${ }^{10}$ Saxegaard juga memaparkan kompleksitas karakter Boas. Walau arti nama Boas adalah kekuatan, namun ia adalah seorang laki-laki tua dan tanpa keturunan. ${ }^{11}$ Boas dikenal seorang yang baik, ramah atau bahkan dapat disebut sebagai seorang pahlawan, namun ia juga seorang yang "cerdik" atau "licin". ${ }^{12}$

$\mathrm{Lu}$ menganalisis beberapa tokoh dari kitab Rut dalam kaitan dengan pola kepemimpinan mereka. ${ }^{13}$ Lu memaparkan karakter kepemimpinan dari: (1) Naomi yang ditandai dengan kesetiaan kepada Allah, kesabaran dan ketabahan; (2) Rut yang menampakkan kesetiaan, keberanian, sikap hormat kepada yang lebih tua dan ketaatan; serta (3) Boas yang menunjukkan sikap hormat, belas kasihan, melindungi yang lemah dan integritas. ${ }^{14}$

Decker membuat perbandingan atau kontras di antara ketiga tokoh perempuan dalam kitab ini untuk memberikan model kerohanian manusia. ${ }^{15}$ Karakter Orpa dibandingkan dengan Rut untuk menggambarkan seorang yang kembali kepada kepercayaan lama. Karakter Naomi dikontraskan secara tajam dengan Rut untuk mengungkapkan bahwa Naomi merupakan model untuk seorang umat Allah yang mempunyai kehidupan seperti seorang yang tidak mengenal Allah, sebaliknya Rut merupakan suatu model bagi seorang yang tidak

${ }^{10}$ Ibid., 128.

${ }^{11}$ Ibid., 145-146.

${ }^{12}$ Ibid., 170.

${ }^{13}$ Yong Lu, "Leadership Characters in the Book of Ruth: A Narrative Analysis," Journal of Corporate Responsibility and Leadership 3, no. 3 (2016): 55-71, http://doi.org/10.12775/ JCRL.2016.016.

${ }^{14}$ Ibid., 55.

${ }^{15}$ Decker membandingkan karakter Rut dan Orpa serta karakter Naomi dan Rut. Lih. Timothy L. Decker, "Contrastive Characterization in Ruth 1:6-22: Three Ways to Return from Exile," Old Testament Essays 32, no. 03 (2019): 908-935, http://doi.org/10.17159/2312-3621/2019/ v32n3a8.

${ }^{16}$ Ibid., 908.

${ }^{17}$ Richard L. Pratt Jr., Ia Berikan Kita Kisah-Nya (Surabaya: Momentum, 2005). Pratt sendiri tidak pernah menulis tafsir kitab Rut berdasarkan pendekatannya. Ia mengenal Allah, namun kemudian menjadi pengikut Allah yang setia. ${ }^{16}$

Artikel ini bertujuan untuk melengkapi pelbagai hasil penelitian analisis penokohan di atas untuk menyelidiki tokoh-tokoh dalam kitab Rut (Naomi, Rut dan Boas) dan menemukan kompleksitas gambaran ketiga tokoh itu melalui perbandingan di antara ketiganya. Analisis tokoh ini dilakukan untuk memperlihatkan motif penulis kitab Rut yang dengan sengaja mengungkapkan keagungan tokoh Rut secara tidak langsung dan samar dengan tujuan mempengaruhi respons pembaca mulamula.

\section{METODE PENELITIAN}

Penulis menggunakan analisis tokoh yang dikemukakan oleh Richard L. Pratt, Jr. untuk menganalisis dan membandingkan ketiga tokoh utama kitab Rut, yaitu Naomi, Rut dan Boas, guna menemukan tujuan penokohan dalam kitab Rut dan mengidentifikasi respons pembaca. ${ }^{17}$ Penulis berpendapat bahwa penulis kitab Rut dengan sengaja mengungkapkan keagungan tokoh Rut secara tidak langsung dan samar. Tokoh Rut dalam keagungannya sebagai wanita yang cakap ('êšet hayil) ${ }^{18}$ yang menyatakan kasih setia (hesed) kepada sesamanya dihadirkan dalam bayang-bayang keasingannya (sebagai perempuan Moab) dan tokoh utama lainnya, seperti Naomi dan Boas. ${ }^{19}$ Hal ini penting, karena melaluinya

hanya menyinggung beberapa hal berkaitan kitab Rut dalam buku ini, seperti penyebutan ritual dahulu penanggalan kasut dalam kaitan dengan penebusan (4:7) sebagai petunjuk komposisi final kitab Rut yang mempunyai jarak yang jauh dengan peristiwa yang dikisahkan. Juga penyebutan silsilah yang berhenti pada Daud dapat menjadi petunjuk bahwa kitab ini disusun pada zaman Daud. Ibid., 266-267. Ia hanya menulis pengantar singkat kitab Rut. Lih. Richard L. Pratt Jr., ed., NIV Spirit of the Reformation Study Bible (Grand Rapids: Zondervan, 2003).

${ }^{18}$ Istilah ini muncul dalam Rut 3:11 dan diterjemahkan dengan beberapa istilah, seperti "perempuan baik-baik" (LAI), a woman of excellence (NASB), a worthy woman (ESV).

${ }^{19}$ Nama Rut paling sedikit disebut 12 kali, sedangkan nama Naomi muncul 22 kali dan nama Boas muncul 20 kali. Lih. Saxegaard, Character Complexity, 106. Selain itu, Bal menyatakan bahwa dalam ranah pribadi (private) Naomi 
dapat diperkirakan bagaimana respons pembaca mula-mula. ${ }^{20}$ Orang Israel yang merupakan pembaca kitab Rut akan tersindir atau tergelitik hatinya oleh karena menemukan ada seorang yang tidak hanya seorang asing, tetapi juga seorang perempuan Moab yang merupakan musuh yang paling dibenci justru mempunyai kehidupan yang lebih saleh daripada mereka. ${ }^{21}$ Pembaca kitab Rut diharapkan dapat mengevaluasi kerohanian mereka sebagai umat Allah dan juga dibangkitkan kesadaran tentang Allah Israel yang terbuka untuk semua bangsa atau pentingnya pemahaman bahwa mereka dengan latar belakang bukan Israel tidak selalu membawa keburukan bagi kehidupan umat Allah.

\section{METODE ANALISIS TOKOH DARI RICHARD L. PRATT JR.}

Pratt mengungkapkan bahwa untuk menemukan petunjuk maksud penulis dalam teks narasi ada empat hal yang harus diperhatikan, yaitu penokohan, penggambaran adegan, struktur narasi dan teknik khusus yang digunakan penulis narasi untuk mengungkapkan sudut pandangnya. ${ }^{22}$ Penokohan berkaitan dengan penelitian terhadap tokoh-tokoh yang muncul, bagaimana tokoh-tokoh tersebut diperankan, dan apa tujuan dalam memberikan banyak perhatian pada tokoh-tokoh tersebut. ${ }^{23}$ Adapun penggambaran adegan itu berkaitan dengan bagaimana adegan itu dibagi, tempat dan waktu dalam adegan, serta bagaimana

ditampilkan lebih menonjol daripada Rut, sedangkan dalam ranah publik Boas ditampilkan lebih menonjol daripada Rut. Lih. Mieke Bal, "Heroism and Proper Names, Or The Fruits of Analogy," dalam A Feminist Companion to Ruth, The Feminist Companion to the Bible 3, ed. Athalya Brenner (Sheffield: Sheffield Academic, 2001), 55.

${ }^{20}$ Pratt menggunakan istilah original audience dan original readers. Lih. Richard L. Pratt Jr., He Gave Us Stories (Phillipsburg: Presbyterian and Reformed, 1993), 148-149, 231.

${ }^{21}$ Alice Ogden Bellis, Helpmates, Harlots, and Heroes: Women's Stories in the Hebrew Bible (Westminster John Knox, 2007), 184. Penulis berpendapat bahwa kitab Rut ini hadir bukan sebagai suatu karya polemik, oleh karena itu tulisan ini tidak bersifat konfrontatif, tetapi lebih bersifat subversif yang tersembunyi. Penulis mendapatkan ide tentang karya sastra yang bersifat subversif tersembunyi dari adegan itu dilukiskan. ${ }^{24}$ Struktur narasi berkaitan penyelidikan alur cerita (plot) yang terdiri dari problem, aksi menanjak, titik balik, aksi menurun dan resolusi (jalan keluar) yang semuanya nampak melalui penyusunan adegan-adegan. ${ }^{25}$ Sedangkan beberapa teknik khusus yang digunakan penulis narasi untuk mengungkapkan sudut pandangnya, seperti pengulangan, rujukan tak langsung (alusi), dan ironi. ${ }^{26}$ Adapun dalam artikel ini penulis hanya berfokus pada penokohan atau penyelidikan karakter.

\section{Penokohan}

Pratt menyatakan bahwa penyelidikan tentang para tokoh narasi meliputi pemaparan tokoh, teknik penokohan dan tujuan penokohan. ${ }^{27}$ Pemaparan tokoh berkaitan dengan tokohtokoh yang ditampilkan dalam narasi, seperti Allah, makhluk supranatural dan manusia. ${ }^{28}$ Pratt juga menyatakan bahwa dalam pemaparan tokoh-tokohnya, penulis Perjanjian Lama (PL) mengungkapkan dengan jujur, sehingga tokoh dihadirkan dalam sisi kebaikan ataupun keburukannya. Penulis PL juga melakukan selektivitas yang berkaitan dengan tujuan utama penulisannya.

Dalam kaitan dengan teknik penokohan, Pratt mengungkapkan tiga hal, yaitu petunjuk penokohan, kedalaman penyingkapan dan pengaturan tokoh. ${ }^{29}$ Untuk memahami karakter tokoh, penulis PL memberikan petunjuk

Eric A. Seibert, Subversive Scribes and the Solomonic Narrative. A Rereading of 1 Kings 1-11 (New York: T\&T Clark, 2006). Pendapat ini berbeda pendapat dengan Jones yang berpendapat bahwa kitab Rut merupakan kritik dan polemik terhadap eksklusivisme pada era Ezra dan Nehemia. Lih. Edward Allen Jones III, Reading Ruth in the Restoration Period: A Call for Inclusion (New York: T\&T Clark, 2016), 152.

${ }^{22}$ Pratt, Ia Berikan Kita Kisah-Nya, 275.

${ }^{23}$ Ibid., 147-170.

${ }^{24}$ Ibid., 173-201.

${ }^{25}$ Ibid., 203-257.

${ }^{26}$ Ibid., 275-280.

${ }^{27}$ Ibid., 148.

${ }^{28}$ Ibid., 148-155.

${ }^{29}$ Ibid., 156. 
penokohan melalui pemaparan aspek penampilan dan segi sosial, tindakan nyata, pikiran dan perkataan langsung, serta komentar deskriptif. ${ }^{30}$ Dalam penyingkapan kedalaman karakternya, penulis PL menggunakan kategori tokoh bundar (round character), tokoh datar (flat character) dan tokoh latar (functionary character). ${ }^{31}$ Dalam kaitan pengaturan tokoh, Pratt mengungkapkan tiga kelompok tokoh, yaitu protagonis, antagonis dan ambivalen. ${ }^{32}$

Melalui penyelidikan teknik penokohan seseorang dapat menemukan tujuan penokohan dari penulis, yaitu untuk menunjukkan perhatian utama, drama dasar dan respons pembaca. ${ }^{33}$ Perhatian utama suatu narasi akan nampak melalui tokoh-tokoh bundarnya. Semakin penuh penjabaran akan tokoh bundar ini, semakin penting tokoh ini dalam suatu kisah. Mengenali tokoh-tokoh dan mengamati interaksi di antara mereka, akan mengarahkan kepada struktur dasar suatu kisah. Ketegangan antara protagonis dan antagonis dapat menunjukkan plot sentral suatu kisah. Pada akhirnya melalui penyelusuran teknik penokohan ini seseorang dapat memperkirakan respons pembaca, karena penulis PL tidak hanya sekedar menampilkan tokoh-tokoh mereka untuk mengungkapkan orang-orang zaman dahulu,

\footnotetext{
${ }^{30}$ Ibid.

${ }^{31}$ Ibid., 161-163. Tokoh bundar adalah tokoh yang dilukiskan dari berbagai sudut, seperti pikiran, perasaan, dan tindakannya, sehingga tokoh ini dimunculkan dengan pelbagai sifatnya dan ditampilkan sebagai "orang yang riil." Tokoh datar adalah tokoh yang ditampilkan berkaitkan dengan sekitar satu karakter atau sifat. Sedangkan tokoh latar adalah tokoh yang disebutkan dalam teks, namun kepribadiannya hampir-hampir tidak diungkapkan.

${ }^{32}$ Ibid., 163-165. Protagonis meliputi tokoh-tokoh utama dan pendukung protagonis (the protagonist's entourage). Antagonis adalah tokoh penting dan pendukung antagonis (the antagonist's entourage) yang diarahkan untuk menentang protagonis. Sedangkan ambivalen adalah tokoh yang tidak jelas atau rancu dalam dukungannya terhadap pemeran protagonis atau antagonis.

${ }^{33}$ Ibid., 166-169.

${ }^{34}$ Block menyatakan bahwa struktur narasi kitab Rut ini adalah sebagai berikut: Pendahuluan (1:1-5), Narasi (1:1:64:21), Babak I: Di tanah Moab: Naomi yang menjadi kosong (1:6-22), Babak II: Di Betlehem: Perjumpaan Pertama Rut dengan Boas (2:1-23), Babak III: Di Tanah Pengirikan: Perjumpaan Kedua Rut dengan Boas (3:1-18), Babak IV: Di
}

tetapi juga untuk membangkitkan respons pembaca mereka. Pembaca dapat memberikan tanggapan yang simpatik, antipati atau campuran keduanya.

\section{PENERAPAN ANALISIS PENOKOHAN DARI RICHARD L. PRATT JR.}

Kitab Rut merupakan suatu kitab yang sederhana alurnya. ${ }^{34}$ Diawali dengan kepindahan keluarga Elimelekh bersama Naomi, istri dan kedua anak lelakinya, Mahlon dan Kilyon yang meninggalkan Betlehem menuju ke Moab oleh karena bencana kelaparan. Ketika tinggal di Moab sebagai pendatang, Elimelekh mati. Selanjutnya Mahlon dan Kilyon menikah dengan Rut dan Orpa yang merupakan perempuan Moab. Kematian kedua anak lelakinya membuat Naomi memutuskan untuk kembali ke tanah Yehuda. Naomi kembali ke tanah airnya hanya bersama dengan Rut, menantunya yang bersikukuh untuk mendampinginya, oleh karena Orpa memutuskan kembali ke keluarganya. Di Betlehem kisah ini berlanjut dengan pertemuan Rut dengan Boas yang merupakan kerabat Elimelekh. Kitab ini diakhiri dengan kisah pernikahan Rut dengan Boas yang didasarkan atas hukum penebusan dan pernikahan levirat, ${ }^{35}$ yang kemudian

Betlehem: Naomi menjadi penuh (4:1-17), dan Kesimpulan (4:18-22). Lih. Block, Ruth, 41.

${ }^{35}$ Istilah levir dalam bahasa latin artinya saudara ipar (brother in law). Hukum pernikahan levirat adalah hukum yang mewajibkan saudara dari laki-laki yang meninggal untuk menikahi janda tanpa anak dari saudaranya yang meninggal itu berdasarkan Ulangan 25:5-10. Ada perdebatan di antara para ahli tentang pernikahan Boas dan Rut merupakan pernikahan levirat atau tidak. Penulis sependapat dengan Block yang menguraikan bahwa pernikahan ini dapat dikatakan sebagai pernikahan levirat, walau pernikahan ini tidak persis sama dengan apa yang diatur dalam Ulangan 25:5-10, karena hal ini seharusnya menjadi tanggung jawab saudara kandung, sedangkan Boas bukan saudara kandung. Block berpendapat bahwa Boas melakukan lebih dari apa yang dituntut dalam hukum pernikahan levirat. Ibid., 89-90, 147-149, 196-213; Sedangkan Jones berpendapat bahwa pernikahan Boas dan Rut tidak dapat disebut sebagai pernikahan levirat. Pernikahan ini mirip dengan kisah pernikahan Tobias dan Sara. Sara adalah janda yang telah kehilangan mati tujuh orang suaminya oleh karena perbuatan setan, sedangkan Tobias tertarik untuk menikahi dan menolong Sara dan ia berhak menikahi Sara oleh karena 
dikaruniai anak bernama Obed, yang adalah kakek dari Raja Daud.

Dalam kaitan dengan kitab Rut, adapun tokoh utama atau bundar adalah Naomi, Rut dan Boas, karena ketiga tokoh ini digambarkan dari berbagai sudut oleh penulis kitab Rut. Elimelekh, Mahlon dan Kilyon, Obed, para perempuan Betlehem dan kerabat yang lebih dekat adalah tokoh-tokoh datar, karena para tokoh ini hanya digambarkan secara sekilas dan singkat. Sedangkan Rahel, Lea, Peres, Tamar, Yehuda (4:11-12) dan nama-nama yang ada dalam silsilah Daud (4:18-22) dapat disebut sebagai tokoh latar, karena mereka hanya disebut dalam teks, namun kepribadian mereka hampir tidak ditampilkan. ${ }^{36}$

Artikel ini akan berfokus pada penyelidikan karakter Naomi, Rut dan Boas yang merupakan tokoh bundar. Ketiga tokoh ini mempunyai frekuensi pemunculan paling sering dibandingkan dengan tokoh-tokoh lainnya. Pemaparan dan teknik penokohan diselidiki melalui pengamatan pemunculan, perkataan dan tindakan para tokoh bundar ini diurut mulai bagian awal pemunculan hingga pada akhir pemunculannya dalam kitab Rut untuk mendapatkan gambaran para tokoh utama ini secara lebih menyeluruh. Dalam artikel ini juga akan diselidiki bagaimana para tokoh bundar ini diatur oleh penulis kitab Rut, yaitu siapa saja yang menjadi protagonis, antagonis, dan ambivalen, serta bagaimana sang penulis kitab Rut mengatur para tokoh ini. Melalui semua penyelidikan ini diharapkan dapat ditemukan apa perhatian utama dari penulis kitab Rut, drama (struktur) dasar kitab Rut dan respons pembaca mula-mula kitab Rut ini. ${ }^{37}$

\section{Naomi}

Nama Naomi muncul sebanyak 22 kali dalam kitab Rut (1:2, 3, 8, 11, 15, 18, 19, 20, 21, 22;

masih ada pertalian keluarga (Tobit 6--7). Lih. Jones, Reading Ruth, 129-137.

${ }^{36}$ Bdk. Pratt, Ia Berikan Kita Kisah-Nya, 162-163.

${ }^{37}$ Bdk. Ibid., 163-170.

${ }^{38}$ Saxegaard, Character Complexity, 76.
$2: 1,2,6,20,22 ; 3: 1 ; 4: 3,5,9,14,16,17)$. Istilah "mertua" yang dikenakan kepada Naomi juga muncul 10 kali, yaitu 1:14; 2:11, 18, 19, 23; 3:1, $6,16,17,18$. Sebutan "isteri" yang menunjuk kepada Naomi sebagai isteri Elimelekh muncul dua kali, yaitu 1:1-2. Memperhatikan frekuensi kemunculan sebanyak 34 kali berkaitan dengan nama Naomi, istilah "mertua" dan "istri" dalam seluruh kitab Rut menunjukkan bahwa Naomi adalah tokoh yang sangat penting dalam kitab ini. Adapun arti nama "Naomi" adalah baik, menyenangkan, kemurahan, dan anugerah. ${ }^{38}$

\section{Perkataan dan Tindakan}

Perkataan Naomi yang pertama diungkapkan dalam konteks meminta Orpa dan Rut, kedua menantu perempuannya itu untuk pulang ke rumah ibu mereka dan tidak mengikutinya untuk kembali ke Betlehem (1:8-9). Ungkapan ketidakberdayaan Naomi juga berlanjut dalam ayat 11-13 yang menyatakan bahwa ketidakmampuannya untuk menyediakan anak laki-laki yang dapat meneruskan status pernikahan bagi kedua menantu perempuannya itu. Raskow menyatakan bahwa perkataan atau perintah Naomi kepada kedua menantunya ini menunjukkan kepahitan dan kekosongan Naomi karena kehilangan suami dan kedua anak lelakinya serta ketidakmampuannya untuk memberikan perlindungan dan masa depan bagi kedua menantu perempuannya itu. ${ }^{39}$ Bagi Naomi yang terbaik adalah bahwa kedua menantu perempuannya itu kembali ke Moab dan tidak mengikutinya. Terhadap desakan Naomi ini, Orpa kembali ke Moab, tetapi Rut tetap bersikukuh mengikuti Naomi, walau Naomi sekali lagi mendesaknya untuk meninggalkannya. Menanggapi tekad dan sumpah Rut untuk tidak meninggalkan Naomi, tetapi tetap bersamanya sekalipun sampai hari kematian, Naomi berhenti berkata-kata kepada Rut dan diam (Rut 1:18). Kisah dalam Rut 1

\footnotetext{
${ }^{39}$ Ilona Raskow, "Ruth: The Discourse of Power and The Power of Discourse," dalam A Feminist Companion to Ruth, The Feminist Companion to the Bible 3, ed. Athalya Brenner (Sheffield: Sheffield Academic, 2001), 29-30.
} 
diakhiri dengan kisah tibanya Naomi dan Rut di Betlehem dan para perempuan Betlehem ini gempar dan berkata: "Naomikah itu?" Hyman menyatakan bahwa pertanyaan ini dapat mempunyai beberapa konotasi oleh karena tergantung pada intonasi pengucapannya yang tidak nampak dalam teks, seperti kaget, sikap kritis atau ketidakpercayaan terhadap perubahan fisik Naomi. ${ }^{40}$ Terhadap pertanyaan para perempuan Betlehem ini, Naomi berkata: "Jangan sebut aku Naomi [menyenangkan], tetapi sebut aku Mara [pahit]" (1:20-21). Hal ini mengungkapkan kepahitan dan kekecewaan Naomi terhadap perlakuan Tuhan kepada dirinya sejak ia meninggalkan Betlehem dan pergi ke Moab. ${ }^{41}$ Naomi digambarkan sebagai karakter yang berani "menolak" nama yang diberikan orang tuanya dan "menggantikan" dengan nama yang dianggapnya sesuai dengan pengalaman hidupnya. ${ }^{42}$ Naomi juga menyatakan bahwa kini dia kembali ke Betlehem dengan tangan kosong, walaupun sebenarnya Rut, menantu perempuannya itu ada bersamanya. Sikap diam Naomi terhadap Rut sejak kepulangan mereka dan juga ketika meresponi para perempuan dapat menunjukkan sikap alienasi Naomi terhadap Rut. ${ }^{43}$

Pasal 2 mengisahkan bahwa Rut meminta izin Naomi untuk pergi memungut sisa panen di ladang orang lain. Terhadap permintaan Rut ini Naomi hanya berkata: "Pergilah, anakku." (2:2). Saxegaard menafsirkan perkataan singkat Naomi ini menunjukkan kepasifan. Naomi seharusnya dapat memberikan petunjuk atau peringatan kepada Rut sebagai perempuan asing untuk selayaknya bersikap dalam kaitan dengan memungut sisa panen. ${ }^{44} \mathrm{Hal}$ ini dapat saja merupakan "buah" dari pengalaman hidup yang pahit dari Naomi. Dalam 2:18-23 diceritakan bahwa ketika Rut pulang memungut dari ladang dengan hasil yang banyak,

\footnotetext{
${ }^{40}$ Ronald T. Hyman, "Questions and Changing Identity in the Book of Ruth," Union Seminary Quaterly Review 39, no. 3 (1984), 192-193.

${ }^{41}$ Ibid., 193.

${ }^{42}$ Bal, "Heroism and Proper Names," 50.

${ }^{43}$ Raskow, "Ruth: The Discourse of Power," 33.
}

Naomi bertanya di mana tempat Rut memungut. Rut menjawab bahwa Boas adalah pemilik ladang. Ketika Naomi mendengar nama itu, Naomi menjadi bergairah dengan mengucapkan berkat bagi Boas dan memberitahukan Rut bahwa orang itu adalah kerabat yang wajib menjadi penebus. Saxegaard mengungkapkan bahwa terjadi perubahan dalam diri Naomi yang mana kepahitan itu berubah menjadi suatu pengharapan. ${ }^{45}$ Rashkow menyatakan bahwa kedukaan dan kepahitan Naomi mulai berakhir dan sejak itu ia mulai menyiapkan suatu rencana bagi Rut untuk dapat menyelesaikan persoalan mereka, yaitu penebusan tanah. ${ }^{46}$ Naomi juga menasihati agar Rut tetap dekat para pengerja perempuan dan bukannya dengan para pengerja lakilaki seperti yang disarankan Boas. Nasihat Naomi ini untuk menjaga Rut agar tidak terlibat hubungan romantis dengan pria lain, selain dari "sang penebus." 47

Dalam pasal 3 semakin jelas melalui perkataan dan tindakannya, Naomi berupaya agar Rut mendapat perlindungan di rumah suami yang baru dan mengatur langkah untuk mendekati Boas. Perintah Naomi kepada Rut untuk mandi, berurap, berpakaian yang bagus dan pergi berbaring dekat Boas di tempat pengirikan merupakan suatu perintah yang berani, beresiko dan dapat saja membahayakan Rut. Ketika pagi hari setelah Rut kembali dari tempat pengirikan, Naomi bertanya ke-

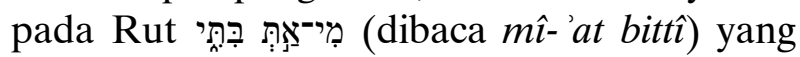
artinya "Siapakah kamu, anak perempuanku?" (3:16). ${ }^{48}$ Pertanyaan Naomi ini bukan karena ia tidak mengenal perempuan yang berdiri di depannya. Naomi pasti mengenali Rut. Melalui pertanyaan ini, Naomi ingin menanyakan status Rut setelah bermalam bersama Boas di pengirikan. Apakah Boas menolaknya? Apakah terjadi sesuatu semalam bersama Boas? Apakah rencana Naomi untuk

\footnotetext{
${ }^{44}$ Saxegaard, Character Complexity, 95-96.

${ }^{45}$ Ibid., 96.

${ }^{46}$ Raskow, "Ruth: The Discourse of Power," 36.

${ }^{47}$ Ibid., 36-37.

${ }^{48}$ LAI menerjemahkan "Bagaimana, anakku?"
} 
menjadikan Rut sebagai istri Boas berhasil? ${ }^{49}$ Setelah Rut menceritakan apa yang Boas katakan dan lakukan, Naomi meminta Rut untuk menunggu apa yang akan dilakukan Boas (3:18).

Dalam pasal 4 tidak terdapat satu perkataan langsung Naomi. Ia seolah dijadikan tokoh yang "pasif" oleh penulis kitab Rut. Setelah Rut menikah dengan Boas dan dikaruniai seorang anak laki-laki, para perempuan Betlehem menyampaikan ungkapan-ungkapan yang menyatakan karya Allah yang memulihkan Naomi, oleh karena Rut telah melahirkan penerus bagi keluarga Naomi. (4:14-15, 17). Naomi tidak berkata apa-apa. Ia hanya mengambil anak itu, meletakkan pada pangkuannya dan mengasuhnya (4:16). Sikap diam atau membisu Naomi tidak harus ditafsirkan negatif, oleh karena diam atau membisu tidak harus berkonotasi tidak senang, mood yang buruk atau tidak bersyukur. ${ }^{50}$ Selanjutnya Saxegaard berpendapat bahwa deskripsi akhir Naomi adalah seorang wanita yang puas, namun tidak dapat menunjukkan sukacita secara langsung. Naomi awalnya hanya berharap untuk mendapatkan makanan di Betlehem, tetapi kini ia juga mendapatkan penebus dan penerus dari keluarganya. ${ }^{51}$

\section{Ringkasan Karakter Naomi}

Kitab Rut menghadirkan kompleksitas dan keambiguan karakter Naomi. ${ }^{52}$ Ia dapat dikategorikan sebagai tokoh yang ambivalen, yaitu tokoh yang tidak jelas atau rancu dalam dukungannya terhadap pemeran protagonis atau antagonis. ${ }^{53}$ Dalam kitab Rut seseorang tidak dapat menemukan tindakan Naomi yang melawan atau memusuhi Rut, walau ada satu tindakan yang dapat membahayakan Rut,

\footnotetext{
${ }^{49}$ Hyman, "Questions and Changing Identity," 199; Raskow, "Ruth: The Discourse of Power," 40.

${ }^{50}$ Saxegaard, Character Complexity, 102.

${ }^{51}$ Ibid., 102.

${ }^{52}$ Bdk. ibid., 103.

${ }^{53}$ Bdk. Pratt, Ia Berikan Kita Kisah-Nya, 165.

${ }^{54}$ Bdk. Saxegaard, Character Complexity, 103.

${ }^{55}$ Fewell dan Gunn, "A Son Is Born to Naomi," 100. Sikap diam Noami ketika Rut bersikukuh ikut dengannya. Naomi
}

yaitu ketika Naomi menyuruh Rut untuk berdandan serta kemudian tidur secara diamdiam dekat Boas di tempat penggirikan. Hal yang menarik dari karakter Naomi adalah sikap diamnya. ${ }^{54}$ Fewell dan Gunn mengungkapkan ada lima sikap diam dalam kitab Rut, yang mana empat sikap diam oleh Naomi dan satu sikap diam oleh Rut. ${ }^{55}$ Naomi berdiam (berhenti berkata-kata) ketika Rut tetap bersikukuh mengikuti Naomi pulang ke Betlehem (1:18). Apakah Naomi senang dengan hal ini? Atau sebaliknya dia merasa jengkel dan terbebani dengan Rut? Naomi juga merasa dirinya sendirian atau "kosong" ketika pulang ke Betlehem, walaupun ada Rut yang menemaninya. Ia juga tidak pernah menceritakan tentang perihal adanya kerabat atau penebus yang dapat menolong mereka. Sikap diam Naomi juga dapat dilihat ketika para perempuan Betlehem berkata kepadanya untuk mengungkapkan pujian kepada Tuhan atas karya pemulihan dalam hidupnya melalui Rut. Para perempuan Betlehem menilai Rut lebih berharga dari tujuh anak laki-laki oleh karena Rut tidak hanya sangat mengasihi Naomi, tetapi juga melahirkan seorang anak laki-laki (4:14-15). ${ }^{56}$ Saxegaard menyatakan bahwa sikap diam Naomi ini merupakan akibat dari sikap Naomi yang mengasihani diri sendiri (self-pity). ${ }^{57}$ Dalam konteks kitab Rut, seseorang dapat memaklumi kondisi ini, oleh karena Naomi memang mengalami penderitaan yang sangat berat. Ia bersama dengan keluarganya merantau ke negeri asing dengan tujuan agar terlepas dari bahaya kelaparan dan menikmati kehidupan yang lebih baik, justru ia harus kehilangan suami dan kedua anak lakilakinya. Suatu pengalaman hidup yang mengerikan bagi setiap orang yang harus melaluinya. Apakah pada akhirnya Naomi tetap hidup dalam kepahitan atau dapat melihat karya

berdiam tentang kehadiran Rut yang bersamanya ketika ia tiba di Betlehem. Naomi diam tentang keberadaan Boas, sang kerabat hingga Rut menceritakan tentang kebaikan Boas di tempat pengirikan. Naomi berdiam tentang Rut pada saat kelahiran Obed. Sedangkan Rut berdiam untuk menceritakan apa yang dia katakan pendapatnya kepada Boas pada saat bertemu keesokan harinya dengan Naomi.

${ }^{56}$ Bdk. ibid 100-103.

${ }^{57}$ Saxegaard, Character Complexity, 103. 
pemulihan Allah dalam dirinya melalui peran Rut, penulis kitab Rut tidak memaparkannya.

Naomi adalah tokoh yang paling sering disebut dan merupakan tokoh yang penting dalam kitab Rut. Oleh karena itu, tidaklah mengherankan jika ada para ahli yang berpendapat bahwa fokus kitab Rut seharusnya adalah Naomi. Brenner mengutip pandangan Goitein yang berpendapat bahwa penulis kitab Rut itu berfokus pada Naomi daripada Rut, oleh karena plot kisah dibuka (1:6) dan diakhiri dengan Naomi (4:17); nasihat Naomi yang menyebabkan kompleksitas dan perkembangan plot kisah (pasal 2-3); dan juga kisah ini diakhiri dengan berkat untuk Naomi dan bukannya untuk Rut. ${ }^{58}$ Selanjutnya Havea juga menyatakan bahwa walaupun kitab ini diberi nama kitab Rut, namun narator juga menempatkan Naomi sebagai tokoh yang penting. Naomi dihadirkan pada awal dan akhir dari kitab ini. ${ }^{59}$

Dari semua penyelidikan di atas dapat disimpulkan bahwa sekalipun Naomi merupakan tokoh yang paling sering disebut dalam kitab Rut dibandingkan dengan tokoh-tokoh lainnya, tetapi Naomi bukanlah tokoh yang terpenting (protagonis) dalam kitab ini. Penulis kitab Rut sengaja memaparkan Naomi sebagai tokoh yang ambigu atau ambivalen. Ada tokoh lainnya yang lebih penting, yang ingin dihadirkan dan disoroti dengan tajam peran dan kehadirannya oleh penulis kitab Rut. Karakter Naomi dengan sengaja digambarkan sebagai tokoh yang ambigu, tidak jelas atau rancu dalam dukungannya terhadap tokoh protagonis dalam kitab ini.

\footnotetext{
${ }^{58}$ Athalya Brenner, "Introduction," dalam A Feminist Companion to Ruth, The Feminist Companion to the Bible 3, ed. Athalya Brenner (Sheffield: Sheffield Academic, 2001), 10.

${ }^{59}$ Jione Havea, "Stirring Naomi: Another Gleaning at the Edges of Ruth 1," dalam Reading Ruth in Asia, ed. Jione and Peter H.W. Lau Havea (Atlanta: SBL, 2015), 114.

${ }^{60}$ Dalam teks Alkitab bahasa Indonesia muncul 18 kali, oleh karena adanya penerjemahan kata ganti orang ketiga perempuan dengan kata Rut dalam 1:18; 2:10, 13, 14, 23; 3:5.
}

\section{Rut}

Nama Rut muncul sebanyak 12 kali dalam teks bahasa Ibrani kitab Rut, yaitu 1:4, 14, 16, 22; $2: 2,8,21,22 ; 3: 9 ; 4: 5,10,13 .{ }^{60}$ Arti nama "Rut" tidak jelas, walau secara tradisional diartikan sebagai "teman" atau "teman perempuan." ${ }^{1}$

Penyebutan istilah "perempuan Moab" digunakan bersama dengan nama Rut dalam 1:4, $22 ; 2: 2,21 ; 4: 5,10$ atau tanpa nama Rut dalam 2:6. Narator menyebutkan pemanggilan ini (Rut, perempuan Moab) sebanyak 4 kali, yaitu Rut 1:4, 22; 2:2, 21. Dua kali narator menyebut nama Rut tanpa dikaitkan dengan perempuan Moab, yaitu di 2:8; 4:13. Boas menyebutkan pemanggilan ini sebanyak 2 kali, yaitu dalam $4: 5,10$. Bujang yang mengawasi para penyabit menyebutkan istilah "perempuan Moab" (tanpa nama Rut) sekali, yaitu Rut 2:6. Secara umum istilah "Moab" mempunyai konotasi negatif, seperti immoralitas, sikap menggoda, musuh dan dewa asing. ${ }^{62}$ Glover mengungkapkan ada tiga bagian Taurat yang menyatakan sikap permusuhan bangsa Moab terhadap Israel, yaitu penolakan untuk memberikan makanan kepada Israel (Ul. 23:3-4), mengupah Bileam untuk mengutuk Israel (Bil. 22:1-7), kelahiran Moab yang merupakan buah hubungan Lot dan anak perempuannya (Kej. 19:30-38). Moab juga digambarkan sebagai bangsa yang mempengaruhi Israel untuk menyembah berhala (Bil. 25:1-3). ${ }^{63}$ Glover berpendapat bahwa penyebutan nama "Rut" tanpa tambahan "perempuan Moab" dalam 4:13 menunjukkan bahwa Rut pada akhirnya telah menjadi bagian dari bangsa Israel melalui pernikahannya dengan Boas. ${ }^{64}$ Penulis tidak setuju dengan pendapat Glover. Bagi penulis penyebutan berulang istilah "perempuan

${ }^{61}$ Saxegaard, Character Complexity, 106.

${ }^{62}$ Ibid., 115.

${ }^{63}$ Neil Glover, "Your People, My People: An Exploration of Ethnicity in Ruth," Journal for the Study of the Old Testament 33, no. 3 (2009): 303, https://doi.org/10.1177/0309 089209102498.

${ }^{64}$ Ibid., 302-303. 
Moab" oleh narator dalam kitab Rut nampaknya sengaja bertujuan untuk tetap mengingatkan "keasingan" Rut terlepas dari pelbagai hal baik yang ia telah lakukan. Penulis kitab Rut sengaja tidak menghapus "keasingan" Rut, karena hal ini penting bagi tujuan penokohan Rut, yaitu ingin mengungkapkan adanya kesalehan dan kesetiaan "orang asing" yang dikontraskan dengan ketidaksalehan, kebobrokan dan ketidaksetiaan bangsa Israel sebagai umat Allah.

Istilah "menantu" juga digunakan untuk menunjuk kepada Rut bersama Orpa (1:6-8) atau untuk Rut saja (1:22; 2:20, 22; 4:15). Istilah ini umumnya digunakan oleh penulis kitab Rut dan hanya sekali oleh perempuan-perempuan Betlehem (4:15). Istilah digunakan untuk menunjukkan dan menekankan relasi Rut sebagai menantu dengan Naomi sebagai mertua. Penggunaan istilah ini dalam Rut 4:15 perlu ditanggapi, karena penggunaannya memuat beberapa hal penting dan menarik. Dalam 4:15 perempuan-perempuan Betlehem menyebut Rut sebagai menantu yang mengasihi Naomi dan melahirkan keturunan bagi Naomi, bahkan Rut sebagai menantu disebut lebih berharga dari tujuh anak laki-laki. Saxegaard mengungkapkan bahwa kasih Rut kepada Naomi berwujud perhatian yang luar biasa dari seorang menantu kepada mertuanya yang tua dan Rut itu "memperkaya" kehidupan Naomi, oleh Rut dinilai lebih berharga daripada tujuh anak laki-laki mengandung ungkapan simbolis, yaitu tentang kelimpahan dan kesempurnaan. ${ }^{65}$

Istilah "anak" atau lebih tepatnya "anak perempuan" juga sering digunakan dalam kitab Rut. Naomi memanggil Orpa dan Rut dengan sebutan ini dalam 1:11. 12, 13, untuk Rut saja dalam 2:2, 22; 3:1, 16, 18; sedangkan Boas menggunakan sebutan ini untuk Rut dalam

\footnotetext{
${ }^{65}$ Saxegaard, Character Complexity, 119-120.

${ }^{66}$ Ibid., 121.

${ }^{67}$ Ibid.

${ }^{68}$ LAI menerjemahkannya "perempuan" (4:11).

${ }^{69} \mathrm{M}$. Daniel, R Carroll, "Once a Stranger, Always a Stranger? Immigration, Assimilation, and the Book of Ruth,"
}

Rut 2:8; 3:10, 11. Dalam kaitan dengan Naomi, sebutan ini mudah untuk dipahami, oleh karena Rut memang adalah menantu perempuan Naomi, sehingga sebutan "anak perempuan" merupakan hal yang biasa untuk mengungkapkan kedekatan dan keintiman hubungan Naomi dengan Rut yang lebih dari sekedar hubungan formal sebagai "menantu perempuan." ${ }^{66}$ Sedangkan dalam kaitan dengan Boas, sebutan ini lebih rumit. Saxegaard mengungkapkan bahwa Boas mengunakan sebutan ini, oleh karena ia dalam posisi sebagai kerabat yang lebih tua dan kaya ${ }^{67}$ Penulis berpendapat bahwa Boas menggunakan sebutan ini untuk menandai perbedaan usia yang besar antara Boas dan Rut, karena ada kemungkinan Boas adalah seorang pria yang sudah tua.

Istilah "perempuan muda" juga digunakan untuk Rut. Boas menggunakan sebutan ini dalam 2:5, sedangkan penduduk Betlehem dan tuatua kota menggunakan sebutan ini dalam $4: 11 .{ }^{68}$ Penulis berpendapat bahwa sebutan ini kemungkinan mengindikasikan bahwa Rut masih muda usianya, walau ia adalah seorang janda.

Rut menggunakan beberapa istilah untuk memperkenalkan atau mendeskripsikan dirinya. Dalam 2:10 ketika ia berjumpa dengan Boas yang menunjukkan kebaikan kepadanya, ia menyebut dirinya sebagai seorang perempuan asing נָכְרִיָּה (nokriyyâ). Istilah nokriyyâ masih mengandung konotasi negatif. Istilah גרי (gêr) merupakan istilah bagi orang asing dengan konotasi lebih positif, oleh karena itu ger lebih dapat diterima oleh komunitas "pribumi." ${ }^{69}$ Rut sebagai menantu Naomi sebenarnya dapat dikategorikan sebagai gēr, namun ia tidak menggunakan istilah ini, tetapi ia menggunakan istilah nokriyyâ, perempuan asing dengan konotasi tidak terlalu positif. ${ }^{70}$ Dalam 2:13, ia menggunakan istilah שִפְָָָה

International Bulletin of Misionary Research 39, no. 4 (2015): 186, https://doi.org/10.1177/239693931503900405.

${ }^{70}$ James K. Hoffmeier, The Immigration Crisis. Immigrants, Aliens, and the Bible (Wheaton: Crossway, 2009), 105. 
(šiphâ) yang berarti "hamba perempuan."71 Saxegaard mengungkapkan bahwa istilah ini digunakan sebagai sikap merendahkan diri dari seseorang ketika memperkenalkan dirinya kepada seseorang yang mempunyai kedudukan sosial yang lebih tinggi. ${ }^{72}$ Dalam 3:9 Rut juga menggunakan istilah lain untuk dirinya, ('âmâ), yang artinya "hamba perempuan." 73 Istilah ini dapat berarti "budak," "hamba" atau "selir." 74 Saxegaard mengungkapkan bahwa Rut menggunakan sebutan ini bersama dengan namanya dalam upaya mendekati Boas lebih intim. ${ }^{75}$ Sedangkan Lau berpendapat bahwa sebutan ini digunakan oleh Rut untuk menyatakan kepada Boas bahwa ia sekarang memenuhi "syarat" untuk menikah dengan Boas. ${ }^{76}$

Istilah lain yang sangat penting adalah "perempuan baik-baik" dalam 3:11. Ungkapan

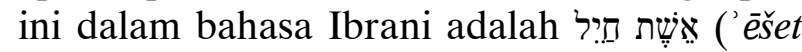
haiyil) yang dapat berarti a woman of excellence (NASB), a worthy woman (ESV). Saxegaard mengungkapkan bahwa istilah ini digunakan untuk Rut oleh Boas untuk menempatkan ia sebagai seorang wanita yang mempunyai kualitas yang baik terlepas dari latar belakangnya yang "rendah" (sederhana). ${ }^{77}$

Hal yang menarik adalah tidak digunakan istilah "janda" untuk Rut, tetapi digunakan istilah "istri orang yang telah mati itu" (4:5) atau isteri Mahlon (4:10). Saxegaard menjelaskan bahwa penggunaan kedua istilah ini untuk Rut oleh Boas bertujuan bukan untuk menunjukkan rasa simpati kepada seorang wanita miskin yang kesepian, tetapi justru memberikan perhatian kepada Mahlon yang dapat kehilangan penerus namanya dan milik pusakanya oleh karena tidak mempunyai keturunan. ${ }^{78}$

\footnotetext{
${ }^{71}$ Terjemahan LAI adalah "hamba."

${ }^{72}$ Saxegaard, Character Complexity, 122.

${ }^{73}$ Terjemahan LAI adalah "hamba."

${ }^{74}$ Saxegaard, Character Complexity, 123.

${ }^{75}$ Ibid., 124.

${ }^{76} \mathrm{Lau}$, Identity and Ethics in the Book of Ruth, 100.

${ }^{77}$ Saxegaard, Character Complexity, 124-125.
}

Jadi, dalam kitab Rut, dapat ditemukan pelbagai istilah atau ungkapan yang dikaitkan dengan tokoh Rut. Terlepas dari status Rut sebagai menantu Naomi yang mendapat panggilan "anak perempuan" atau "menantu perempuan," status keasingan Rut sangat menonjol dalam kitab ini melalui penyebutan berulang kali sebagai "perempuan Moab" oleh penulis kitab. Hal ini nampaknya secara sengaja dilakukan, sehingga setiap orang yang membaca kitab Rut akan selalu mengingat bahwa tokoh Rut adalah seorang perempuan asing, yaitu perempuan Moab.

\section{Perkataan dan Tindakan}

Perkataan Rut yang sangat penting terdapat dalam 1:16-17. Bagian ini mengungkapkan kebulatan tekad atau bahkan sumpah Rut kepada Naomi bahwa ia tidak akan meninggalkan mertuanya, ingin mendampingi mertuanya, tinggal bersama mertuanya, dan hidup bersama di tanah asal mertuanya itu. Ia juga bertekad untuk meninggalkan latar belakangnya dan "merangkul" latar belakang mertuanya. ${ }^{79}$ Jadi ungkapan ini menunjukkan bahwa Rut bersedia meninggalkan segala-galanya untuk mengikut dan mendampingi mertuanya itu.

Dalam 2:2, Rut menyatakan bahwa ingin pergi untuk memungut bulir-bulir jelai. Block menyatakan bahwa Rut adalah seorang wanita yang mau bertindak (woman of action) dan ia lebih berinisiatif daripada Naomi. ${ }^{80}$ Lau juga berpendapat bahwa inisiatif merupakan salah satu karakter utama Rut. ${ }^{81}$ Rashkow menyatakan bahwa Rut tidak meminta izin Naomi, tetapi ia berinisiatif untuk mencari makanan. ${ }^{82}$ Ketika ia di ladang dan menjumpai pengawas ladang, Rut meminta izin untuk memungut dan mengumpulkan jelai (2:7). Rashkow

\footnotetext{
${ }^{78}$ Ibid., 125.

${ }^{79}$ Para ahli terbagi dalam dua kelompok. Ada yang berpendapat bahwa Rut mengalami "pertobatan", tetapi ada juga yang menolak. Bdk. Lau, Identity and Ethics, 92-95.

${ }^{80}$ Block, Ruth, 116.

${ }^{81} \mathrm{Lau}$, Identity and Ethics, 102.

${ }^{82}$ Raskow, "Ruth: The Discourse of Power," 33.
} 
menyatakan bahwa tindakan ini tidak biasa, oleh karena berdasarkan hukum, sebenarnya ia sebagai orang miskin tidak perlu meminta izin dan juga pengawas tidak mempunyai hak untuk memberikan izin. ${ }^{83}$ Tindakan Rut ini sebagai upaya awal mendapatkan keramahtamahan dari sang pemilik tanah. ${ }^{84}$ Ketika berjumpa dengan Boas yang menunjukkan kemurahan hati kepadanya, tindakan Rut sangat dramatis. Ia sujud menyembah dengan mukanya sampai ke tanah dan mengungkapkan kebaikan yang Boas berikan kepadanya, walau ia seorang asing (nokriyyâ) (2:10). Walaupun sebenarnya sebagai menantu perempuan Naomi ia dapat dikategorikan sebagai gêr, Rut menggunakan istilah orang asing yang lebih rendah dari status orang asing yang dapat disandangnya. ${ }^{85}$ Dalam dialog antara Boas dan Rut dalam 2:10-13, ia nampak berupaya keras memenangkan simpati Boas dengan pelbagai strategi, seperti penggunaan ungkapan "aku ini seorang perempuan asing" dan istilah "tuan" untuk Boas, sedangkan istilah "hamba" bagi dirinya. ${ }^{86}$ Tindakan dan perkataan Rut itu pada akhirnya menarik simpati Boas untuk lebih memberikan perhatian khusus kepadanya (2:14-16). Sekembalinya dari ladang, Rut menceritakan kepada mertuanya tentang pemilik ladang di mana ia memungut dan pesan Boas untuk tetap memungut di ladangnya $(2: 19,21)$. Naomi menasihati Rut untuk dekat dengan para pengerja perempuan (2:21-22). Ia menuruti nasihat Naomi dengan memungut dekat dengan para pengerja perempuan (2:23).

Pasal 3 mengisahkan bagaimana Naomi mengupayakan dan menyusun rencana agar Rut mendapat tempat perlindungan melalui pernikahan. Rut menuruti perintah Naomi untuk mandi, berurap, berdandan, pergi ke tempat pengirikan untuk berbaring dekat Boas (3:5). Ketika Boas tersadar bahwa ada perempuan berbaring dekatnya, Rut memberikan respons

\footnotetext{
${ }^{83}$ Ibid., 34.

${ }^{84}$ Ibid.

${ }^{85}$ Ibid., 35.

${ }^{86}$ Daniel dan Carroll, "Once a Stranger, Always a Stranger," 186.
}

yang berbeda dengan perintah Naomi. Naomi memerintahkan Rut untuk menunggu apa yang hendak Boas beritahukan kepadanya mengenai apa yang harus dilakukannya (3:4), tetapi Rut berinsiatif meminta Boas mengembangkan sayapnya untuk melindunginya oleh karena Boas adalah seorang kaum yang wajib menebusnya (3:9). ${ }^{87}$ Rut mampu menggunakan jendela kecil yang dibukakan oleh Naomi dan juga Boas melalui permintaannya kepada Boas untuk menikahinya. ${ }^{8}$ Ini merupakan tindakan yang cerdas dan cerdik dari Rut. Tindakan inilah yang menyebabkan Boas melontarkan pujian kepada Rut dengan menyebutnya sebagai 'ēšet hayil, perempuan baik-baik atau perempuan cakap (3:11), serta ingin menebusnya (3:10-15). Pasal 3 berakhir dengan kisah kembalinya Rut kepada Naomi, ibu mertuanya lalu menceritakan apa yang terjadi di tempat penggirikan dan bagaimana ia menuruti nasihat Naomi untuk menanti hal yang akan terjadi. Hal ini merupakan akhir dari peran aktif Rut dalam kitab ini karena tidak ada dialog atau perkataan yang Rut ucapkan. Seolah-olah peran aktif Rut telah selesai dalam pasal 3 .

Pasal 4 hanya mengisahkan bahwa Rut akhirnya ditebus oleh Boas dan menjadi istri Boas lalu melahirkan seorang anak laki-laki. Bahkan Ketika, atas karunia Tuhan, ia melahirkan seorang anak laki-laki yang menjadi leluhur raja Daud, anak laki-laki ini pun dipandang oleh para perempuan Yerusalem sebagai anak Noami. $^{89}$

\section{Ringkasan Karakter Rut}

Penulis berpendapat bahwa tokoh Rut ini merupakan tokoh yang terpenting dalam kitab ini. Secara hati-hati, penulis kitab menghadirkan Rut dari pribadi yang "kurang" berarti menjadi seorang pahlawan wanita, atau dengan kata lain, from zero to heroine. Walau arti

\footnotetext{
${ }^{87}$ Raskow, "Ruth: The Discourse of Power and The Power of Discourse," 39.

${ }^{88} \mathrm{Lau}$, Identity and Ethics in the Book of Ruth, 105.

${ }^{89}$ Block, Ruth, 231.
} 
namanya tidak jelas, namun tindakannya yang luar biasa dapat diselusuri dalam kitab ini. Panganiban menyatakan bahwa Rut merupakan contoh seorang yang mempunyai resilience di tengah kerapuhannya. ${ }^{90}$ Resilience itu nampak dalam kehidupan Rut dan didasarkan atas hesed yang terwujud melalui sikap menerima kesulitan dan kematian sebagai realitas hidup, menjaga gambar diri yang tetap positif dan mempunyai fokus dan komitmen untuk peduli kepada sesama atau orang lain. Block mengungkapkan bahwa Rut merupakan perwujudan prinsip dasar perjanjian umat Allah, yaitu mengasihi Allah dengan segenap hati dan mengasihi sesama seperti diri sendiri. $^{91}$ Ia juga menyatakan bahwa Rut mewakili umat manusia, yang jauh dari sempurna, oleh karena latar belakangnya sebagai perempuan Moab yang merupakan simbol kebobrokan manusia. Namun, Allah dapat mengangkatnya menjadi bagian dari keluarga perjanjian dan bahkan melibatkannya dalam rencana-Nya untuk menyatakan anugerah dan kebaikan-Nya yang terbuka bagi semua manusia. ${ }^{92}$ Glover menyatakan bahwa Rut melakukan pelbagai tindakan yang luar biasa, yaitu menyatakan kebaikan $(1: 8 ; 3: 10)$, rajin (2:7), membuat pria tua (Boas) sangat gembira (4:10), memberikan Naomi seorang anak laki-laki (4:15) dan seorang raja bagi bangsa Israel (4:17).$^{93}$ Lau menyatakan bahwa melalui kelahiran Obed, Rut adalah seorang "penebus" bagi Naomi dan juga memulihkan kehidupan Naomi. ${ }^{94}$ Walau penulis kitab dengan sengaja berulang menggunakan sebutan "perempuan Moab" bagi Rut, namun kehidupan Rut hadir untuk "menepis" stereotip (pandangan negatif) tentang bangsa Moab. ${ }^{95}$ Bangsa Moab yang pernah menolak memberikan roti kepada bangsa Israel (U1. 23:3-4)

\footnotetext{
${ }^{90}$ Alicia Besa Panganiban, "Theology of Resilience Amidst Vulnerability in the Book of Ruth," Feminist Theology 28, no. 2 (2020): 196, https://doi.org/10.1177/09667 35019886077.

${ }^{91}$ Block, Ruth, 238.

${ }^{92}$ Ibid., 261.

${ }^{93}$ Glover, "Your People, My People," 303. Dalam artikel ini Glover berpendapat bahwa Rut pada akhirnya dapat diterima sebagai bangsa Israel secara implisit, oleh karena tidak ada ungkapan langsung, tetapi melalui penyebutan
}

digantikan dengan tindakan Rut yang menyediakan roti bagi Noami. Bangsa Moab yang dikenal sebagai penyembah berhala dan mempengaruhi bangsa Israel untuk menyembah berhala (Bil. 25:1-3) digantikan dengan tindakan Rut untuk meninggalkan kepercayaan lamanya dan mengikuti Allah Israel. Kisah leluhur Moab yang ditandai hubungan sedarah (inses) dalam peristiwa Lot dan kedua anak perempuannya (Kej. 19:30-38) digantikan dengan tindakan Rut yang tidak merayu Boas di tempat pengirikan, tetapi mengingatkan Boas akan tanggung jawabnya sebagai seorang penebus $(3: 9) .{ }^{96}$

Walaupun namanya paling sedikit disebut di antara para tokoh utama (Naomi, Rut, dan Boas), namun peran Rut ada di semua pasal kitab ini. Kesetiaan, kerajinan dan kecerdasan menandai karakter Rut beriringan dengan pengulangan sebutannya sebagai perempuan Moab yang menandai keasingannya. Nampaknya penulis kitab Rut ingin menghadirkan keagungan Rut secara halus dan samar oleh karena ia seorang perempuan Moab.

\section{Boas}

Nama Boas muncul sebanyak 20 kali dalam kitab Rut, yaitu 2:1, 3, 4, 5, 8, 11, 14, 15, 19, 23; $3: 2,7,14,15 ; 4: 1,5,8,9,13,21$. Frekuensi pemunculan tokoh Boas dalam kitab Rut ini juga menunjukkan Boas sebagai salah satu karakter penting dalam kitab ini. Nama Boas mempunyai arti kekuatan dan kuasa. ${ }^{97}$

Kitab ini menyebut Boas dengan beberapa panggilan atau istilah yang umumnya mengungkapkan relasinya dengan Elimelekh. Pasal 2:1 menyatakan bahwa Boas adalah sanak dari

nama Rut saja dan menghilangkan istilah perempuan Moab dalam Rut 4:13, yang sebelumnya sering dikenakan bersama dengan nama Rut (1:22; 2;2, dll.).

${ }^{94} \mathrm{Lau}$, Identity and Ethics, 97, 101. Lau juga berpendapat bahwa Rut telah mengalami transformasi dari perempuan asing menjadi pribadi yang terhisap dalam masyarakat Israel, bahkan menjadi leluhur Israel.

${ }^{95}$ Glover, "Your People, My People," 303.

${ }^{96}$ Ibid., 303-4.

${ }^{97} \mathrm{Lau}$, Identity and Ethics, 55. 
suami Naomi (Elemekh) yang merupakan seorang yang kaya raya. Istilah "seorang kaya

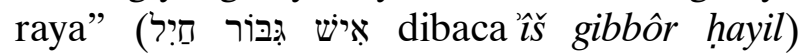
mempunyai arti seorang yang mempunyai kedudukan tinggi oleh karena kekuatan ekonomi dan sosialnya atau dapat dipahami sebagai seorang "tokoh masyarakat." 98 Dalam 2:20 Boas disebut oleh Naomi sebagai "kerabat yang wajib menebus." Pasal 3:9 mengungkapkan bahwa Rut menyebut Boas sebagai seorang penebus, tetapi dalam 3:12, Boas menolak menerima sebutan ini dan menyatakan ada seorang penebus lain yang lebih dekat dibandingkan dirinya. Dalam kaitan dengan penggunaan istilah "penebus" yang digunakan oleh Naomi, Rut dan Boas, Saxegaard mengungkapkan bahwa ketiga orang ini menggunakan istilah penebus ini dengan pemahaman yang berbeda-beda. ${ }^{99}$ Naomi pasti tahu bahwa Boas bukanlah sang penebus yang sebenarnya dalam kaitan dengan hukum pernikahan levirate. Rut mungkin menggunakan istilah ini tanpa mempunyai pemahaman benar yang utuh. Sedangkan Boas tahu dengan jelas bahwa ia bukanlah sang penebus yang "utama." Terlepas dari perbedaan pemahaman tentang "penebus," istilah ini tetap menunjukkan adanya hubungan kekerabatan antara Boas dengan keluarga suami Naomi, Elemekh.

\section{Perkataan dan Tindakan}

Pasal 2:4 menyatakan bahwa ketika Boas berjumpa dengan para pekerjanya, dialah yang pertama mengucapkan salam kepada mereka. Ungkapan "TUHAN kiranya menyertai kamu sekalian" berfungsi sebagai salam dan berkat yang mengungkapkan kepercayaan Boas. ${ }^{100}$ Selanjutnya Block menyatakan bahwa hal ini menciptakan suatu lingkungan dan suasana

\footnotetext{
${ }^{98}$ Saxegaard, Character Complexity, 149; Block, Ruth, 116; Lau, Identity and Ethics, 56.

${ }^{99}$ Saxegaard, Character Complexity, 150.

${ }^{100}$ Block, Ruth, 126.

${ }^{101}$ Ibid.

${ }^{102}$ Philip F. Esler, “'All That You Have Done ... Has Been Fully Told to Me': The Power of Gossip and the Story of
}

kerja yang ditandai dengan anugerah dan kasih setia. ${ }^{101}$

Pasal 2:5-7 menggambarkan percakapan Boas dengan pengawas pekerjanya dalam kaitan dengan rasa ingin tahu tentang kehadiran seorang perempuan asing di ladangnya. Pengawas pekerjanya ini memberikan informasi yang jelas dan akurat tentang siapa perempuan asing itu, yaitu menantu Naomi dari berasal dari Moab. Esler menyatakan bahwa sang pengawas itu tidak mengungkapkan hal yang negatif tentang Rut, bahkan sebaliknya mengungkapkan hal yang positif bahwa ia telah memungut sejak pagi. ${ }^{102} \mathrm{Hal}$ ini menyebabkan Boas tidak bertanya lebih lanjut oleh karena ia telah mendapat informasi yang lengkap tentang Rut. Pertemuan pertama dan percakapan awal antara Boas dan Rut dicatat dalam 2:8-10 dan menunjukkan sifat kebapaan Boas yang murah hati terhadap Rut dengan memberikan perlindungan dan pertolongan kepada wanita asing ini. ${ }^{103}$ Percakapan kedua antara Boas dan Rut dalam 2:11-13 menunjukkan kemampuan Boas untuk melihat kualitas positif Rut. Ungkapan "telah dikabarkan orang kepadaku dengan lengkap segala sesuatu yang engkau lakukan" (ay. 11) menunjukkan bahwa Boas telah mendapatkan informasi yang rinci dan dapat dipercaya tentang kebaikan dan kesetiaan Rut. ${ }^{104}$ Percakapan ketiga antara Boas dan Rut dalam ayat 14 makin menunjukkan kemurahan hati Boas kepada Rut melalui undangan makan bersamanya dan para pekerjanya. Dalam ayat 15-16 juga diungkapkan bahwa Boas memerintahkan para pengerjanya untuk berlaku baik kepada Rut dan memberikan keleluasaan yang luar biasa bagi Rut untuk memungut gandum. Tindakan Boas ini melebihi tuntutan Taurat dalam kaitan dengan izin orang miskin untuk memungut sisa panen. ${ }^{105}$

Ruth,” Journal Biblical of Literature 137, no. 3 (2018): 659, https://doi.org/10.15699/jbl.1373.2018.348544.

${ }^{103}$ Block, Ruth, 129-131.

${ }^{104}$ Esler, "All That You Have Done," 600.

${ }^{105}$ Block, Ruth, 137. 
Block tidak mengarahkan kebaikan dan kemurahan Boas kepada Rut ini sebagai sesuatu yang mengandung ketertarikan romantis, oleh karena penghalang rasial dan sosial di antara mereka, dan juga Rut belum mengetahui bahwa Boas adalah salah satu kerabat almarhum suaminya. ${ }^{106}$ Esler berpendapat bahwa ketika Boas menyadari identitas Rut, maka timbullah keinginan untuk menolongnya dan di kemudian hari nampak tindakan Boas ini lahir dari ketarikan kepada perempuan Moab ini. ${ }^{107}$ Lau berpendapat bahwa tindakan Boas ini terutama lahir dari identitasnya secara sosial atau dalam komunitas sebagai "tokoh masyarakat," walau ada juga unsur ketertarikan kepada Rut. ${ }^{108}$ Penulis berpendapat bahwa dari sisi Rut memang belum ada sesuatu yang berbau romantis, tetapi dari segi Boas, penulis berpendapat bahwa mulai ada ketertarikan Boas terhadap Rut, khususnya kalau memperhatikan kemurahan hati atau kebaikan yang sangat "berlebihan" terhadap Rut. ${ }^{109}$ Bagi penulis ini merupakan salah satu perwujudan karakter "cerdik" atau "licin" dari Boas. ${ }^{110}$ Terlepas dari hal ini, semua tindakan Boas berupa kebaikan, penerimaan, kemurahan hati itu merupakan perwujudan kasih setia (hesed) kepada wanita asing ini. ${ }^{111}$

Pasal 3 mengisahkan interaksi selanjutnya antara Rut dan Boas di tempat pengirikan. Atas saran Naomi, Rut berdandan dan menyiapkan dirinya untuk pergi ke tempat pengirikan dan berbaring dekat Boas (ay. 3-7). Di tengah malam Boas menyadari ada seorang perempuan berbaring di dekatnya, kemudian ia bertanya tentang identitas perempuan ini dan mendengar jawaban bahwa perempuan itu adalah Rut yang memintanya untuk menjadi penebusnya (ay. 8-9). Walau situasi malam itu tidak digambarkan oleh penulis kitab Rut, dapat diduga bahwa ada nuansa erotis namun

\footnotetext{
${ }^{106}$ Ibid., 135-137.

${ }^{107}$ Esler, "All That You Have Done," 659.

${ }^{108} \mathrm{Lau}$, Identity and Ethics, 83.

${ }^{109} \mathrm{Hal}$ yang serupa juga diungkapkan oleh Esler, "All That You Have Done," 659-661.
}

tidak berlanjut kepada hubungan seksual. Malahan Boas memberikan pujian yang luar biasa kepada Rut dan berkeinginan untuk menebusnya (ay. 10-13). Boas memuji kebaikan dan kesetiaan Rut yang tidak hanya dinyatakan kepada keluarga Naomi, tetapi juga kepada dirinya dengan tidak meninggalkannya demi mengejar pria yang lebih muda. ${ }^{112}$ Yang menjadi pertanyaan adalah apakah tindakan Boas kepada Rut pada malam itu merupakan tindakan yang lahir dari keagungan moral yang tidak ingin melakukan sesuatu yang tidak patut atau "ketidakmampuan" Boas oleh karena usianya yang telah lanjut. ${ }^{113}$ Selanjutnya Boas meminta Rut untuk merahasiakan kehadirannya di tempat pengirikan dan kemudian memberikan sejumlah jelai untuk Rut bawa pulang keesokan harinya (ay. 13-15).

Pasal 4 mengisahkan bagaimana upaya Boas untuk menikahi Rut secara resmi. Oleh karena ada penebus lain yang lebih berhak, maka Boas mengajukan perkaranya kepada tua-tua kota Betlehem. Dalam ayat 3 diungkapkan bahwa ada informasi tentang rencana penjualan tanah warisan keluarga Elimelekh oleh Naomi. Dalam kaitan dengan proses upaya mendapatkan Rut, nampak kecerdikan Boas dalam mengatur hal ini. Esler mengungkapkan bahwa Boas sadar akan keindahan karakter Rut, keberadaan penebus yang lebih berhak dari dirinya dan informasi tentang rencana penjualan tanah warisan oleh Naomi, lalu ia dapat menggunakan semuanya itu untuk mencapai tujuannya, yaitu menikahi Rut. ${ }^{114}$ Dalam pertemuan dengan tua-tua Betlehem dan penebus yang lebih berhak, Boas tidak langsung mengangkat masalah penebusan Rut, tetapi ia mengangkat perihal rencana penjualan tanah warisan keluarga Elimelekh sebagai langkah awal dalam upaya mendapatkan Rut. Pada awalnya penebus yang lebih

\footnotetext{
${ }^{110}$ Karakter "licin" (tricky) dari Boas ini diungkap oleh Saxegaard untuk menunjukkan kompleksitas karakter Boas (Saxegaard, Character Complexity, 170).

${ }^{111}$ Block, Ruth, 137.

${ }^{112}$ Esler, "All That You Have Done," 663.

${ }^{113}$ Block, Ruth, 179.

${ }^{114}$ Esler, "All That You Have Done," 665.
} 
berhak ini setuju untuk menebus dengan membeli tanah warisan Elimelekh, namun ketika didengar bahwa penebusan ini juga berkaitan dengan tanggung jawab untuk menikahi janda kerabatnya yang mana seorang perempuan Moab, maka penebus yang lebih berhak ini membatalkan keinginannya dan menyerahkan haknya kepada Boas. Penulis berpendapat bahwa hal ini merupakan "kecerdikan" atau "kelicinan" Boas. ${ }^{115}$ Jika Boas langsung mengutarakan keinginan untuk menikahi Rut, dapat saja tua-tua Betlehem mempunyai keengganan melangkahi hak penebus yang lebih berhak dan mengijinkan Boas untuk menikahi Rut. Boas juga menggunakan keengganan penebus yang lebih berhak untuk menikahi Rut, oleh karena penebus yang lebih berhak ini dapat dikatakan tidak terlalu mengenal Rut seperti Boas. Bagi penebus yang lebih berhak ini Rut hanyalah seorang janda kerabatnya yang merupakan seorang perempuan Moab, tetapi bagi Boas, Rut adalah seorang wanita yang mempunyai karakter yang luar biasa dan layak untuk diperjuangkan menjadi isterinya.

\section{Ringkasan Karakter Boas}

Umumnya Boas digambarkan sebagai tokoh yang kaya raya, baik dan murah hati, ${ }^{116}$ namun melalui pembacaan yang teliti kitab Rut ada sisi lain karakter Boas yang dapat ditemukan. Saxegaard mengungkapkan bahwa walau arti nama Boas adalah kekuatan, namun Boas adalah seorang laki-laki tua dan tanpa keturunan. ${ }^{117}$ Bal mengutip puisi tentang Boas dan Rut oleh Victor Hugo yang mana Boas juga digambarkan sebagai seorang yang mudah tertidur (endormi), oleh karena Boas tertidur lelap, walau ada seorang wanita yang tengah berupaya mendekatinya. ${ }^{118}$ Walau Boas disebut

\footnotetext{
${ }^{115}$ Block membahas panjang lebar tentang kompleksitas perihal penebusan tanah dan juga dalam kaitannya dengan Rut. Ia juga berpendapat bahwa tindakan Boas ini dilatarbelakangi bukan oleh belas kasihan kepada Rut ataupun faktor ekonomi, tetapi lebih didasarkan pada keyakinan dan tanggung jawab moral untuk menegakkan nama keturunan Elimelekh. Boas melakukan hal yang melebihi tuntutan hukum. Ia melakukan spirit of the law dan tidak hanya letter of the law. Lih. Block, Ruth, 212-224.
}

seorang yang berkuasa (powerful atau potent), tetapi kenyataannya ia adalah the sleeper, the weak, the impotent. ${ }^{119}$ Penulis juga sependapat dengan Saxegaard yang menilai bahwa Boas juga merupakan seorang yang "cerdik" atau "licin." 120 Ketika ia mulai melihat kualitas karakter Rut yang menimbulkan ketertarikannya, Boas menabur benih kebaikan semaksimal mungkin yang tentunya menarik hati Rut dan juga Naomi, mertua Rut. Ketika ia menyadari bahwa ada penebus lain yang lebih berhak, ia pun mengambil langkah cerdik yang pada akhirnya dapat menikahi Rut secara legal. Bagi penulis, Boas adalah tokoh protagonis yang berfungsi untuk membantu tokoh utama lainnya dalam kitab ini.

\section{TUJUAN PENOKOHAN}

Dari uraian analisis karakter di atas dapat disimpulkan bahwa penulis kitab ingin menampilkan Rut sebagai tokoh atau karakter utama dengan cara yang samar, tidak langsung atau dalam bayangan Naomi dan Boas sebagai tokoh utama lainnya. Boas adalah tokoh protagonis yang berfungsi mendukung Rut sebagai tokoh utama, sedangkan Naomi adalah tokoh yang ambivalen atau rancu, karena dalam tindakan-tindakannya tidak jelas apakah ia mendukung atau justru melawan Rut sebagai tokoh utama. Nama Rut memang paling sedikit disebut di antara para tokoh utama kitab Rut (Naomi, Rut, dan Boas), namun perannya ada di semua pasal kitab ini. Melalui penyelusuran kitab Rut dapat ditemukan bahwa dalam ranah pribadi (private) Naomi ditampilkan lebih menonjol daripada Rut, sedangkan dalam ranah publik Boas ditampilkan lebih menonjol daripada Rut. ${ }^{121}$ Interaksi antara Naomi dan Rut dalam ranah pribadi memang menunjukkan bahwa peran Naomi lebih me-

\footnotetext{
${ }^{116} \mathrm{Lau}$ berpendapat bahwa Boas merupakan contoh sempurna pribadi yang hidup dalam kasih setia (Lau, Identity and Ethics, 87).

${ }^{117}$ Saxegaard, Character Complexity, 145-146.

${ }^{118} \mathrm{Bal}$, "Heroism and Proper Names," 51.

${ }^{119}$ Ibid.

${ }^{120}$ Saxegaard, Character Complexity, 170.

${ }^{121}$ Bal, "Heroism and Proper Names," 55.
} 
nonjol, seperti dalam mengalami keputusan untuk kembali ke tanah Yehuda, menasihati menantunya ini untuk kembali kepada orang tuanya, menasihati untuk bekerja di dekat para pengerja perempuan di ladang Boas, mengatur dan mempersiapkan Rut untuk meminta Boas untuk menjadi penebusnya. Sedangkan Rut nampaknya hanya menjadi pelaku perintah dan nasihat Naomi, kecuali dalam hal tekadnya untuk tetap mengikut Naomi pulang ke tanah Yehuda. Dalam hal interaksi Rut dan Boas tampak bahwa Boas lebih menunjukkan peran dominannya, seperti menyuruh Rut untuk hanya memungut sisa panen di ladangnya, memerintahkan para pekerjanya untuk berlaku ramah dan baik kepada Rut, meminta Rut untuk menunggu untuk penyelesaian hal penebusannya dan mengatur pertemuan dengan tua-tua kota dan kerabat yang lebih dekat. Rut juga nampak hanya menuruti dan melakukan perintah dan nasihat Boas. Namun, di balik semuanya itu, justru Rut mempunyai peran yang sangat penting dalam interaksi antara ketiga tokoh ini. Pemulihan Naomi dan "kelengkapan atau kesempurnaan Boas" yang merupakan tokohtokoh utama dalam kitab ini tergantung pada Rut. Bagaimana Naomi dipulihkan dari kehilangan dan kepahitan, amat "bergantung" pada Rut. Naomi mendapatkan penebusan tanah dan anak dari hukum pernikahan levirat melalui pernikahan Rut. Dalam kaitan dengan interaksi antara Boas dan Rut, "kelengkapan atau kesempurnaan" Boas sebagai pria yang kaya dan berkuasa dapat dinyatakan bahwa hal itu juga "bergantung" pada Rut. Boas tidak bertindak langsung menolong Naomi, kerabatnya yang mengalami keterpurukan. Hanya melalui hubungan dengan Rut, Boas dapat menjalankan peran sebagai kerabat yang berhak menebus tanah dan pernikahan levirat. Boas, pria yang "tua" dan kaya raya ini pada akhirnya dapat membentuk suatu keluarga dan menjadi leluhur bagi Daud, raja Israel yang besar itu melalui pernikahan dengan Rut. Tokoh Rut adalah tokoh yang menjadi jawaban para tokoh utama lainnya, sehingga

${ }^{122}$ Panganiban, “Theology of Resilience”, 185. dapat dikatakan bahwa Rut merupakan tokoh yang terpenting dalam kitab ini. Tokoh Rut hadir tanpa ada hal negatif yang dikaitkan dalam dirinya, kecuali hanya keasingannya yang sering diulang. ${ }^{122} \mathrm{Hal}$ ini tentu berkaitan dengan tujuan penokohannya yang akan mempengaruhi respons pembaca.

\section{IDENTIFIKASI RESPONS PEMBACA MULA-MULA}

Pratt menyatakan bahwa hasil analisis tokoh akan membangkitkan tiga tipe tanggapan utama, yaitu simpati, antipati dan campuran. Simpati adalah suatu respons pembaca yang menghargai dan mengagumi sikap, perilaku dan sifat dari tokoh suatu narasi. Antipati adalah suatu respons pembaca yang menolak, tidak menyukai atau bahkan menimbulkan perasaan hina di hati pembaca terhadap sikap dan sifat dari tokoh suatu narasi. Sedangkan campuran adalah gabungan respons simpati dan antipati pembaca terhadap tokoh suatu narasi yang dihadirkan oleh penulisnya dalam figur positif yang juga ditandai dengan sifat negatifnya, atau figur negatif yang ditandai oleh beberapa sifat positifnya. ${ }^{123}$ Dalam upaya mengidentifikasi respons pembaca terhadap ketiga tokoh utama kitab Rut, yaitu Naomi, Rut dan Boas, penulis berpendapat bahwa respons pembaca dapat berupa simpati, antipati dan campuran.

Terhadap tokoh Naomi, respons pembaca dapat berupa campuran, tetapi lebih banyak kepada respon antipati. Pembaca dapat mempunyai respons simpati, oleh karena melihat pergumulan kehilangan Naomi yang luar biasa, yaitu kehilangan suami dan kedua anak laki-lakinya. Tetapi pembaca juga dapat mempunyai respons antipati yang lebih kuat, karena melihat bahwa (1) Naomi ini begitu terikat dengan perasaan kehilangan dan kepahitan, sehingga kurang dapat melihat kehadiran dan peran Rut dalam kehidupannya; (2) ketidakpedulian terhadap bahaya yang dapat saja dialami oleh Rut sebagai perempuan asing

\footnotetext{
${ }^{123}$ Pratt, Ia Berikan Kita Kisah-Nya, 168-170.
} 
untuk memungut sisa panen di ladang orang; (3) rencana yang berbahaya untuk mengatur pertemuan yang bernuansa seksual antara Rut dan Boas di tempat pengirikan; dan juga (4) sikap diamnya di tengah pujian dan sukacita perempuan-perempuan Yerusalem atas kelahiran Obed dan kesetiaan Rut, menantunya itu. Jadi, respons pembaca terhadap tokoh Naomi bersikap campuran, walau mungkin lebih banyak kepada respons antipati.

Pembaca juga dapat mempunyai respons campuran terhadap Boas, walau mungkin lebih banyak kepada respons simpati. Pembaca dapat menemukan Boas sebagai seorang tokoh yang kaya raya, baik dan murah hati. Ia bersikap hormat terhadap para pekerjanya. Ia menyatakan kemurahan hati kepada semua orang, khususnya kepada Rut. Ia menjaga kehormatan Rut dalam pertemuan tengah malam di tempat pengirikan. Ia juga berupaya melakukan upaya penebusan dan menikahi Rut, walau ada kerabat lain yang lebih dekat. Tetapi pembaca juga dapat mempunyai respons sedikit antipati, ketika merenungkan motif Boas untuk menikahi Rut, oleh karena Boas adalah seorang pria tua dan nampak sikap yang tricky dalam proses penebusan dan upaya menikahi Rut. Jadi penulis berpendapat bahwa respons pembaca terhadap tokoh Boas lebih bersifat simpatik, walau ada sedikit antipatinya.

Dalam upaya mengidentifikasi respons pembaca terhadap tokoh Rut, penulis berpendapat bahwa tokoh Rut ini membangkitkan respons simpati bagi pembacanya. Pembaca dapat menemukan pelbagai sikap dan sifat Rut yang positif, di antaranya: (1) kesetiaan Rut kepada Naomi mertuanya; (2) kerelaannya untuk

\footnotetext{
${ }^{124}$ Jones berpendapat bahwa kitab Rut merupakan suatu karya polemik atau kritik terhadap eksklusivisme di era Ezra dan Nehemia yang menegaskan bahwa keberadaan dan peran positif orang asing di Israel sangat penting bagi pemulihan Israel untuk menjadi bangsa yang besar lagi. (Jones, Reading Ruth, 152). Bellis menyatakan adanya unsur subversif dari kisah Rut (Bellis, Helpmates, Harlots, and Heroes, 185-186). Seibert menggunakan istilah secretive subversive dalam kaitan dengan tulisan yang bertujuan mempengaruhi pembaca untuk meninggalkan ideologi penguasa dan
}

meninggalkan keluarga dan tanah airnya; (3) inisiatifnya untuk pergi memungut sisa panen; (4) kerajinannya; serta (4) sikap yang bijak dan rendah hati sebagai seorang perempuan asing di tengah masyarakat lain. Pembaca menemukan kebaikan dan kesetiaan Rut melalui mulut pekerja Boas, Boas sendiri dan perempuanperempuan Betlehem. Penulis berpendapat bahwa penulis kitab Rut itu sengaja menghadirkan pelbagai kelebihan dan keagungan Rut ini secara tidak menyolok, samar atau dalam bayangan Naomi dan Boas sebagai tokoh utama lainnya. Hal ini sangat penting, oleh karena Rut tidak hanya seorang perempuan asing, tetapi juga seorang perempuan Moab yang merupakan musuh yang paling dibenci oleh bangsa Israel, justru mempunyai kehidupan yang lebih saleh daripada mereka. Jika kelebihan Rut ini dihadirkan terlalu mencolok atau bersifat polemik, hal ini justru dapat menimbulkan respons antipati. Pembaca yang merupakan bangsa Israel dapat saja tersinggung dan tidak menyukai narasi ini, sehingga mereka kehilangan kesempatan untuk belajar sesuatu yang sangat penting, yaitu bagaimana seorang perempuan Moab itu dapat memperlihatkan kehidupan seorang umat Allah dengan menyatakan kasih setia kepada sesamanya. Penulis berpendapat bahwa kitab Rut ini hadir bukan sebagai tulisan polemik atau konfrontatif, tetapi lebih bersifat subversif yang tersembunyi. ${ }^{124}$ Pembaca akan tersindir atau tergelitik hatinya untuk melihat suatu kenyataan rohani yang luar biasa, yaitu ada seorang perempuan Moab yang mempunyai kehidupan yang lebih saleh daripada mereka, bahkan pada akhirnya mempunyai peran sebagai leluhur dari Raja Daud. Pembaca kitab Rut juga diharapkan dapat mengevaluasi kehidupan mereka sebagai umat Allah dan

membuka diri terhadap ideologi yang diungkapkan oleh penulis secara tersembunyi. Pola tulisan ini digunakan oleh mereka yang kurang mempunyai kekuasaan atau keberanian secara terbuka mengkritik pandangan dominan yang berkuasa, karena akan membahayakan penulisnya. Sedangkan untuk tulisan subversif yang terbuka Seibert menggunakan istilah conspicuous subversive (Seibert, Subversive Scribes and The Solomonic Narrative, 16-17). 
juga terbangkitkan kesadaran tentang Allah Israel yang terbuka untuk semua bangsa dan pentingnya pemahaman bahwa orang dengan latar belakang bukan Israel atau asing tidak selalu membawa keburukan bagi kehidupan umat Allah, tetapi dapat memberikan teladan rohani bagi mereka.

\section{KESIMPULAN}

Analisis tokoh utama kitab Rut menolong untuk dapat menemukan tujuan penokohan dalam kitab tersebut dan mengidentifikasi respons pembacanya. Penulis berpendapat bahwa nampak kecerdikan penulis kitab Rut dalam menghadirkan secara tidak langsung atau samar keagungan Rut dengan latar belakang seorang perempuan Moab sebagai tokoh utama yang menyatakan iman sejati dalam wujud kasih dan kesetiaan kepada sesamanya. Keagungan Rut tidak dihadirkan dalam bentuk tulisan polemik atau bersifat konfrontatif, tetapi justru disamarkan, sehingga diharapkan bahwa keagungan Rut ini dapat menyusup dalam hati pembaca kitab ini. Para pembaca atau pendengar kisah ini diharapkan dapat mengevaluasi kehidupan mereka sebagai umat Allah dan juga terbangkitkan kesadaran bahwa Allah Israel itu terbuka untuk semua bangsa. Mereka pun dapat membuka diri bagi bangsa lain dan memahami bahwa bangsabangsa lain tidak selalu membawa keburukan bagi kehidupan umat Allah. Keindahan dan kedalaman kitab Rut itu lebih daripada sekadar kisah cinta antara Rut dan Boas.

\section{DAFTAR PUSTAKA}

Bal, Mieke. "Heroism and Proper Names, or the Fruits of Analogy." Dalam A Feminist Companion to Ruth, The Feminist Companion to the Bible 3, diedit oleh Athalya Brenner, 42-69. Sheffield: Sheffield Academic, 2001.

Bar-Efart, Shimon. Narrative Art in the Bible. Decatur: Almond, 1989.

Bellis, Alice Ogden. Helpmates, Harlots, and Heroes: Women's Stories in the Hebrew Bible. Ed. ke-2. Louisville: Westminster
John Knox, 2007.

Block, Daniel I. Ruth. Zondervan Exegetical Commentary on the Old Testament. Grand Rapids: Zondervan, 2015.

Brenner, Athalya. "Introduction." Dalam $A$ Feminist Companion to Ruth, The Feminist Companion to the Bible 3, diedit oleh Athalya Brenner, 9-18. Sheffield: Sheffield Academic, 2001.

Daniel, M. dan R. Carroll. "Once a Stranger, Always a Stranger? Immigration, Assimilation, and the Book of Ruth." International Bulletin of Misionary Research 39, no. 4 (2015): 185-188. https://doi.org/ 10.1177/239693931503900405.

Decker, Timothy L. "Contrastive Characterization in Ruth 1:6-22: Three Ways to Return from Exile." Old Testament Essays 32, no. 03 (2019): 908-935. http://doi.org/ 10.17159/2312-3621/2019/v32n3a8.

Esler, Philip F. "“All That You Have Done ... Has Been Fully Told to Me': The Power of Gossip and the Story of Ruth.” Journal of Biblical Literature 137, no. 3 (2018): 646-666. https://doi.org/10.15699/jbl.13 73.2018.348544.

Fewell, Danna Nolan dan David M. Gunn. "'A Son Is Born to Naomi!': Literary Allusions and Interpretation in the Book of Ruth." Journal for the Study of the Old Testament 40 (1988): 99-108.

_. "Boaz, Pillar of Society: Measures of Worth in The Book of Ruth." Journal for the Study of the Old Testament 45 (1989): 45-59.

Glover, Neil. "Your People, My People: An Exploration of Ethnicity in Ruth." Journal for the Study of the Old Testament 33, no. 3 (2009): 293-313. https://doi.org/10.1177/ 0309089209102498.

Havea, Jione. "Stirring Naomi: Another Gleaning at the Edges of Ruth 1." Dalam Reading Ruth in Asia, diedit oleh Jione dan Peter H.W. Lau Havea, 111-124. Atlanta: SBL, 2015.

Hoffmeier, James K. The Immigration Crisis. Immigrants, Aliens, and the Bible. Wheaton: Crossway, 2009.

Hyman, Ronald T. "Questions and Changing 
Identity in the Book of Ruth." Union Seminary Quaterly Review 39, no. 3 (1984): 189-201.

Jones, Edward Allen, III. Reading Ruth in the Restoration Period. A Call for Inclusion. New York: T\&T Clark, 2016.

Lau, Peter H.W. Identity and Ethics in the Book of Ruth. A Social Identity Approach. Berlin: Walter de Gruyter, 2010.

Lu, Yong. "Leadership Characters in the Book of Ruth: A Narrative Analysis." Journal of Corporate Responsibility and Leadership 3, no. 3 (2016): 55-71. http://doi.org/10.127 75/JCRL.2016.016.

Nazarov, Konstantin. "Focalization in The Old Testament Narratives with Specific Examples from the Book of Ruth." Tesis, University of Chester, 2018.

Panganiban, Alicia Besa. "Theology of Resilience amidst Vulnerability in the Book of Ruth." Feminist Theology 28, no. 2 (2020): 182-197. https://doi.org/10.1177/
0966735019886077.

Pratt, Richard L., Jr. He Gave Us Stories. Phillipsburg: Presbyterian and Reformed, 1993.

_. Ia Berikan Kita Kisah-Nya. Surabaya: Momentum, 2005.

Pratt, Richard L., Jr., ed. NIV Spirit of the Reformation Study Bible. Zondervan, 2003.

Raskow, Ilona. "Ruth: The Discourse of Power and The Power of Discourse." Dalam A Feminist Companion to Ruth, The Feminist Companion to the Bible 3, diedit oleh Athalya Brenner, 26-41. Sheffield: Sheffield Academic, 2001.

Saxegaard, Kristin Moen. Character Complexity in the Book of Ruth. Tübingen: Mohr Siebeck, 2010.

Seibert, Eric A. Subversive Scribes and The Solomonic Narrative. A Rereading of 1 Kings 1-11. New York: T\&T Clark, 2006. 